scandal. Yet this time, according to some, Dr. Lundberg simply went too far and, as a result, he has been made to pay a very high price: his career. Of course, it could have been worse. Thank goodness he didn't choose an article about the ill effects of cigars...

Robert H. Keller, B.A., B.C.L., LL.B'01

Student, Faculty of Law, McGill University

\title{
REFERENCES
}

1. Kolata G. AMA drops journal editor over sex paper. New York Times. January 16: A10; 1999.Cultural Respect

\section{CONGRATULATIONS FROM THE EDITOR OF THE MCGILL MEDICAL JOURNAL (1942)}

Dear MJM:

I learned with great pleasure of the success of the McGill Journal of Medicine. Judging by its content, I think this new journal fully deserves the praise it has received from other journals $(1,2)$.

The McGill Journal of Medicine has a predecessor called the McGill Medical Journal, which published regularly from 1931. I was Editor-in-Chief in 1942. Our principal aim was to stimulate research by students, and I think we succeeded in this. Then, as now, the Faculty of Medicine at McGill encouraged students to engage in research and publish their results.

Here at the University of Virginia, we also encourage students to engage in research. It is good to know that a journal now exists that especially welcomes papers by medical and other students. I will encourage our students to submit articles to the McGill Journal of Medicine.

With good wishes for the further success of your endeavors.

Ian Stevenson

M.D., McGill University, Class of 1943

Carlson Professor of Psychiatry

Division of Personality Studies

University of Virginia Health Sciences Center

\section{REFERENCES}

1. NEJM 336: 885; 1997

2. JAMA 278: 1461-2; 1997 